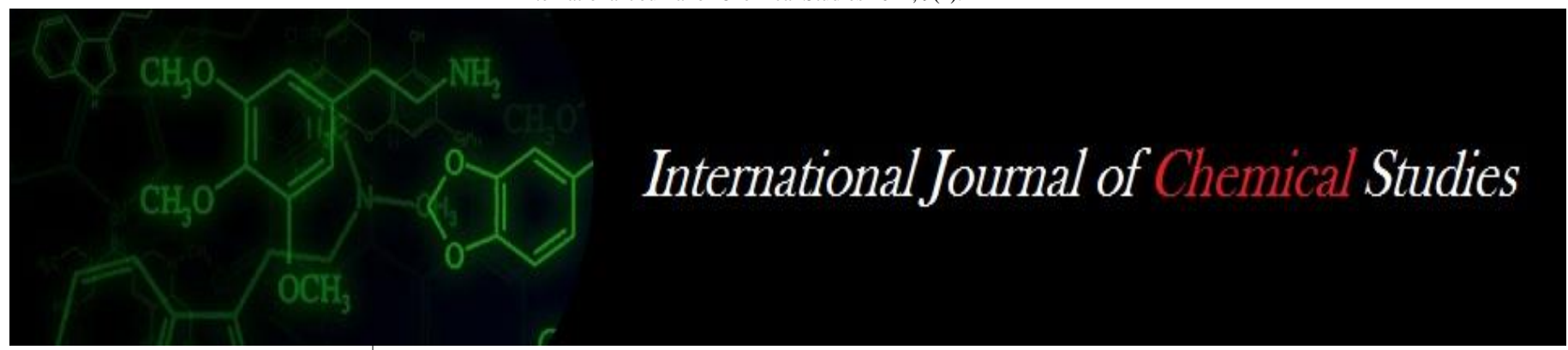

P-ISSN: 2349-8528

E-ISSN: 2321-4902

www.chemijournal.com

IJCS 2021; 9(1): 1242-1244

(C) 2021 IJCS

Received: 02-10-2020

Accepted: 09-11-2020

Sanjulata

Department of Agricultural

Microbiology, Indira Gandhi

Krishi Vishwavidyalaya, Raipur,

Chhattisgarh, India

Dr. Diptimayee Dash

Department of Agricultural

Microbiology, Indira Gandhi

Krishi Vishwavidyalaya, Raipur,

Chhattisgarh, India

Dr. Tapas Chowdhury

Department of Agricultural

Microbiology, Indira Gandhi

Krishi Vishwavidyalaya, Raipur,

Chhattisgarh, India
Corresponding Author: Sanjulata

Department of Agricultural Microbiology, Indira Gandhi Krishi Vishwavidyalaya, Raipur, Chhattisgarh, India

\section{Application of plant growth promoting Rhizobacteria in combination with Biopesticides in controlling major insect pests of cauliflower}

\author{
Sanjulata, Dr. Diptimayee Dash and Dr. Tapas Chowdhury
}

DOI: https://doi.org/10.22271/chemi.2021.v9.i1r.11392

\begin{abstract}
The present investigation was conducted to know the effect of PGPR and biopesticides viz., T1 (Absolute control), T2 (Application of chemical pesticides), T3 (Inoculation of PGPR), T4 (Application of Trichoderma), T5 (Inoculation of PGPR + Neem cake), T6 (Application of Trichoderma +Neem cake), T7 (Inoculation of PGPR +Trichoderma + Neem cake). The experiment comprised of 7 different treatment combinations and four replication. Results from the study indicated that combined Inoculation of PGPR +Trichoderma + Neem cake along with seedling treatment gave significantly higher plant height $(25.83 \mathrm{~cm})$, number of clean leaves (18.75/plant), incidence of aphids in leaves $(0.25)$, survival percentage $(94.66 \%)$,shoot dry weight $(9.03 \mathrm{~g})$, root dry weight $(3.47 \mathrm{~g})$, head weight $(473.43 \mathrm{~g})$. Therefore, it may be concluded that combined Inoculation of PGPR + Trichoderma + Neem cake along with seedling treatment was the most effective treatment combination for higher growth and yield in Cauliflower.
\end{abstract}

Keywords: Cauliflower, PGPR and biopesticide

\section{Introduction}

Cauliflower is among the world's most important vegetable crops grown in the winter. It is cultivated for its white tender curd or head. The edible portion is known as 'curd'. India is the world's biggest producer of cauliflower and is cultivated throughout the country in India (Dhaliwal, 2017) ${ }^{[1]}$. The area wise, Bihar, Odisha, and West Bengal rank first, second, and third, whereas production wise, Bihar, West Bengal and Uttar Pradesh rank first, second, and third, respectively. (Dhaliwal, 2017) ${ }^{[1]}$. In India cauliflower cultivation covers in 414,000 ha with an output of 7,897,000 metric tonnes (Department of Agriculture, GOI 2016) ${ }^{[4]}$. It is grown in Himachal Pradesh as a cash crop that yields remunerative returns to both the small and the marginal hill farmers. Cauliflower is a large feeder of the mineral elements. An adequate supply of nutrients from different sources of inorganic and organic nutrients would significantly increase the yield and quality of the crops. Microbial inoculation in vegetable crops has greatly improved growth, yield, and quality. Cauliflower is well known for cholesterol reduction and improving the immune system. It is also rich in calcium and minerals. Many diseases like damping off, downy mildew, leaf spot, powdery mildew, etc., affect cauliflower and cause huge economic loss. So biocontrol is one way to reduce these diseases in cauliflower.

Biofertilizers increased the efficiency of nitrogen fertilizer, and subsequently increases the yield and quality of cauliflower (Bashyal, 2011) ${ }^{[3]}$. However information on the performance of the cauliflower varieties seedling dipping inoculation with Azotobactor and PSB containing bio-inoculants is still meagre for the terai-zone of West Bengal. Keeping this in view, the present experiment was undertaken to study the effect of seedling dipping with bioinoculants on growth, yield and quality parameter of different cauliflower varieties.

It was determined that the bacterial applications could be able to increase plant growth, germination rate of seed, improve transplant emergence, response to stress conditions and protect from disease. Bacteria strains of Azospirillum, Pseudomonas and Azotobacter have significant impact on seed germination and transplant growth [Shaukat et al. 2006; Nezarat and Gholami, 2009] ${ }^{[2]}$. 


\section{Materials and Methods}

The present investigation on effect of PGPR on growth, yield and incidence of insect/pest in cauliflower was carried out in the Rabi season in 2019-20 at the Department of Agricultural Microbiology, College of Agriculture, Raipur, Chhattisgarh. The experiment was laid out in completely randomized design with four replications comprising seven treatments, viz., T1 (Absolute control),T2 (Application of chemical pesticides), T3 (Inoculation of PGPR), T4 (Application of Trichoderma), T5 (Inoculation of PGPR + Neem cake), T6 (Application of Trichoderma +Neem cake), T7(Inoculation of PGPR + Trichoderma + Neem cake). PGPR was inoculated through seedling dip before transplanting as per treatment and curd formation stage. The plants were planted at a spacing of 45 $\mathrm{cm}$ each way and thus the numbers of plants per treatment 12 . The seedling were transplanted on 5th November' 2019. The effect of different treatments were observed and noted that maximum plant height, No. of leaf/plant, weight of curd, incidence of aphids in leaves, damage leaves per plant, survival percentage, shoot dry wt. (g/plant) and root dry wt. (g/plant). Four plants were randomly selected and tagged in each treatment to study the plant growth and yield characteristics. Data on different growth and yield parameters were analyzed statistically and significance of result was verified. The statistical analysis of the data recorded in all observations was carried out as prescribed by Panse and Shukhatme, 1978. Comparison of the treatments was made with the help of critical differences (C.D.).

\section{Result and Discussion}

Effect of PGPR and Biopesticides on plant survival and growth parameter of cauliflower

Experimental results in cauliflower clearly showed that maximum plant height $(8.82,18.08,23.91,29$ and $25.83 \mathrm{~cm}$, respectively) under the treatment T3, T6 and T7 (Inoculation of PGPR, Application of Trichoderma +Neem cake and Inoculation of PGPR + Trichoderma +Neem cake) was observed at 15, 30, 45, 60 days after transplantation (DAT) and at harvest followed by T4, T5, and T3 i.e. Application of Trichoderma, Inoculation of PGPR and Inoculation of PGPR + Neem cake were statistically very close to each other. However, the treatment effects due to T3, T4, T5 and T7 were statistically at par for increase in plant height from DAT and at harvest. The minimum plant height 7.22, 15.28, 19.57, 20.18 and $19.96 \mathrm{~cm}$ was observed in treatment $\mathrm{T} 1$ at 15,30 , 45, 60 DAT and at harvest.

Table (1) showed significant highest survival percentage in cauliflower $(94.66 \%)$, recorded in treatment $\mathrm{T} 7$ (Inoculation of PGPR + Trichoderma + Neem Cake) and treatment T1 (Absolute control) recorded lowest survival percentage $(78.00 \%)$.

In cauliflower, the maximum shoot dry weight was recorded in T7 (Inoculation of PGPR + Trichoderma + Neem Cake) (9.03) followed by T3 and T5 (Inoculation of PGPR and PGPR + Neem cake) (8.35 and8.52). Whereas maximum root dry weight was recorded in T7 (Inoculation of PGPR + Trichoderma + Neem Cake) (3.47) shown in Table (1).

Table (2) shows the effect of various treatments on the number of clean leaves per plant in cauliflower. The maximum number of clean leaves was observed under the treatment of T7 (Inoculation of PGPR + Trichoderma + Neem Cake) 18.75 , the minimum number of clean leaves per plant was 15.25 in $\mathrm{T} 1$ (Absolute Control) and T2 (Application of chemical pesticides).

Table (2) (fig.1) shows the effect of various treatments on the number of damaged leaves per plant in cauliflower. The maximum number of damaged leaves was observed under the treatment $\mathrm{T} 1$ (Absolute Control) 3.25, the minimum number of damaged leaves per plant was observed in $\mathrm{T} 7$ (Inoculation of PGPR + Trichoderma + Neem Cake) 1.00.

Table (2) (fig.1) shows the effect of various treatments on the incidence of aphids in cauliflower leaves. The maximum incidence of aphids was 3.46 observed under the treatment of T1 (Absolute Control). The minimum incidence of aphids was observed in T7 (Inoculation of PGPR + Trichoderma + Neem Cake) 0.25 .

Table (3) shows that in cauliflower the treatment $\mathrm{T} 7$ (Inoculation of PGPR + Trichoderma + Neem cake) recorded the maximum fruit yield $(473.43 \mathrm{~g})$ which was at par with T5 $(457.50 \mathrm{~g})$ followed by T3 $(421.64 \mathrm{~g})$ and $\mathrm{T} 6(413.38 \mathrm{~g})$. The minimum fruit yield/plant was recorded in treatment $\mathrm{T} 1$ (Absolute control) (256.08g). The treatment T2 (343.34g) and T4 (410.75g) were at par with each other.

Table 1: Efficacy of PGPR and Biopesticides on survival and growth parameter of cauliflower

\begin{tabular}{|c|c|c|c|c|}
\hline Treat- ments & Treatment details & Survival (\%) & Shoot DW (g/plant) & Root DW (g/plant) \\
\hline $\mathrm{T}_{1}$ & Control & 78.00 & $5.64^{\mathrm{d}}$ & $2.55^{\mathrm{c}}$ \\
\hline $\mathrm{T}_{2}$ & chemical pesticides & 78.60 & $6.57^{\mathrm{c}}$ & $2.87^{\mathrm{b}}$ \\
\hline $\mathrm{T}_{3}$ & PGPR & 85.33 & $8.35^{\mathrm{ab}}$ & $3.05^{\mathrm{b}}$ \\
\hline $\mathrm{T}_{4}$ & Trichoderma & 85.33 & $7.67^{\mathrm{b}}$ & $2.95^{\mathrm{b}}$ \\
\hline $\mathrm{T}_{5}$ & PGPR + Neem cake & 91.66 & $8.52^{\mathrm{a}}$ & $3.45^{\mathrm{a}}$ \\
\hline $\mathrm{T}_{6}$ & Trichoderma + Neem cake & 85.33 & $7.72^{\mathrm{b}}$ & $3.02^{\mathrm{b}}$ \\
\hline $\mathrm{T}_{7}$ & PGPR + Trichoderma +Neem cake & 94.66 & $9.03^{\mathrm{a}}$ & $3.47^{\mathrm{a}}$ \\
\hline \multicolumn{7}{r}{} & - & 0.729 & 0.305 \\
\hline
\end{tabular}

Table 2: Effect of PGPR and Biopesticides on incidence of insect/ pests in cauliflower

\begin{tabular}{|c|c|c|c|c|}
\hline Treat-ments & Treatment details & Damaged leaves per plant & No. of Aphids in leaves & No. of clean leaves/plant \\
\hline $\mathrm{T}_{1}$ & Control & 3.25 & 3.46 & 15.25 \\
\hline $\mathrm{T}_{2}$ & Chemical pesticides & 2.33 & 0.83 & 15.25 \\
\hline $\mathrm{T}_{3}$ & PGPR & 1.75 & 0.83 & 16.50 \\
\hline $\mathrm{T}_{4}$ & Trichoderma & 1.75 & 0.67 & 15.75 \\
\hline $\mathrm{T}_{5}$ & PGPR + Neem cake & 1.25 & 0.67 & 17.25 \\
\hline $\mathrm{T}_{6}$ & Trichoderma + Neem cake & 1.33 & 0.58 & 16.5 \\
\hline $\mathrm{T}_{7}$ & PGPR +Trichoderma + Neem cake & 1.00 & 0.25 & 18.75 \\
\hline
\end{tabular}


Table 3: Efficacy of PGPR and Biopesticides on yield of cauliflower

\begin{tabular}{|c|c|c|c|}
\hline Treatments & Treatment details & Total No. of curds from 4 plants & Weight/Curd (g) \\
\hline $\mathrm{T}_{1}$ & Control & 2 & $256.08^{\mathrm{e}}$ \\
\hline $\mathrm{T}_{2}$ & chemical pesticides & 3 & $343.34^{\mathrm{d}}$ \\
\hline $\mathrm{T}_{3}$ & PGPR & 4 & $421.64^{\mathrm{bc}}$ \\
\hline $\mathrm{T}_{4}$ & Trichoderma & 4 & $410.75^{\mathrm{c}}$ \\
\hline $\mathrm{T}_{5}$ & PGPR + Neem cake & 4 & $457.50^{\mathrm{ab}}$ \\
\hline $\mathrm{T}_{6}$ & Trichoderma +Neem cake & 4 & $413.38^{\mathrm{c}}$ \\
\hline $\mathrm{T}_{7}$ & PGPR +Trichoderma +Neem cake & 4 & $473.43^{\mathrm{a}}$ \\
\hline \multicolumn{2}{r}{} & - & 36.19 \\
\hline
\end{tabular}

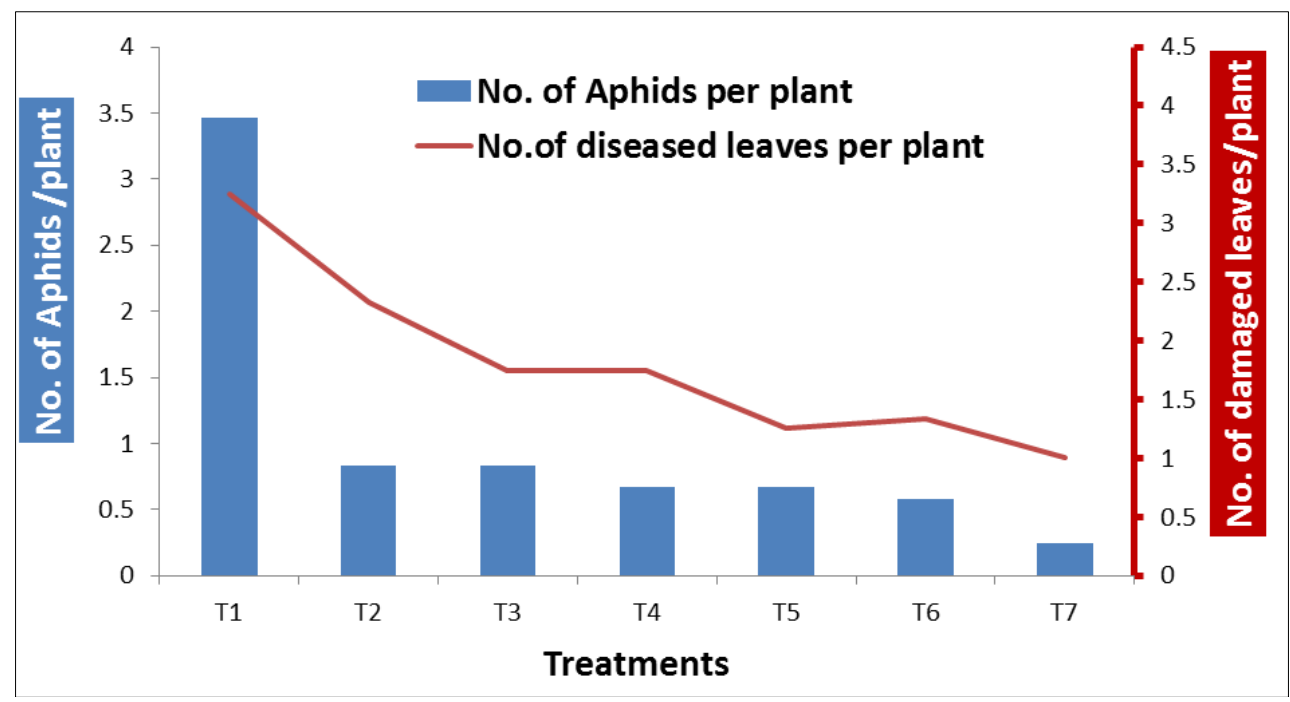

Fig 1: Effect of PGPR and Biopesticides on incidence of insect/ pests in cauliflower

\section{Conclusions}

Based on the results of pot experiments and taking into account input cost. It can be concluded that inoculation of PGPR and Biopesticides has proven to be the best treatments with regard to the growth performance, fruit yield of cauliflower besides it was effective in reducing insect/pests.

\section{Acknowledgement}

The authors feel privileged to thank to IGKV University, Raipur, (C.G.) for providing the financial support to carry out the research work.

\section{Reference}

1. Dhaliwal MS. Hand book of vegetable crops, Edition, $3^{\text {rd }}$, cole crops, Punjab agricultural university 2017, 148-176.

2. Shaukat K, Affrasayab S, Hasnain S. Growth responses of Heliantus annus to plant growth promoting rhizobacteria used as a biofertilizer. J Agric. Res 2006; 1:573-581.

3. Bashyal LN. Response of cauliflower to nitrogen fixing biofertilizer and graded levels of nitrogen. J Agri. Env 2011;12:41-50.

4. Department of agriculture. Horticulture statistics at a glance, 200.1st ed. Ministry of Agriculture \& Farmer Welfare, GOI. Delhi, India: Oxford University Press 2016.

5. Jothy W, Srividya Shivakumar. Growth Promotion and efficacy of cauliflower by plant growth promoting bacterial consortia. Advances in Bioresearch 2018;9(4):43-47. 